\title{
Designing a Model for Assessing the Relationship between Organizational Citizenship Behaviors and Customer Satisfaction (Kerman Saderat Bank as Case Study)
}

Seyed Ali Siadat

Associate Professor, Faculty of Educational Sciences and psychology, Educational

Sciences, University of Isfahan, Isfahan, Iran

s.a.siadat@ui.ac.ir

Mohammad Mohammadi Sadr (Corresponding author)

MA student, Faculty of Educational Sciences and psychology, Educational Sciences and,

University of Isfahan, Isfahan, Iran

mohammadisadr@gmail.com

Received: June 03, 2012 Accepted: June 28, 2012 DOI: 10.5296/jpag.v2i2.2044

\begin{abstract}
Now a days, customer satisfaction (CS) has been considered as one of the most important factors for organizational success. Implementation of customer satisfaction assessment systems is one of most indices in order to improving organizational performance. Customer satisfaction plays important roles in banking industry. Organizational citizenship behaviors (OCB) of bank personnel will change the customer satisfaction and directly affects bank performance. Because of these important interactions between OCB and CS in banking industry, this paper intentionally this investigated process by using PCA and PFA techniques. Results of this study indicated that CS has significant relationship with staff employee's relationships while personal features of employees and OCB has direct impacts on CS. Also detailed analysis revealed that responsibility factor of employee's social relationships and trustworthiness factor of personal employees are the most important factors of OCB in CS assessment.
\end{abstract}

Key words: customer satisfaction, organizational citizenship behaviors, principal component analysis, and principal factor analysis 


\section{Introduction}

Nowadays organizations, efforts to create new needs and wants in their customers and modern consumers based concepts of new marketing and to maintain their loyalty in order to increase profitability through avoiding from exertion and bureaucracy and applying customer's participation and consumer relationship management. However it should be mentioned that the main motivation of organizational success and progress is their customers. In other words, any businesses can't survive without customers. Therefore, it is critical that each organization design a framework to analyze and evaluate status of their customer's satisfaction. Only the organizations and businesses which increase their competitive abilities through increasing quality of their products and services with respect to customer's needs and wants will be successful. The banking industry, that is one of the basic and critical components of each economic system in market-based economy, has very important and critical role in terms of customer satisfaction (Hafezi et al, 2008). Evaluating amount of customer's satisfaction from banking services requires conducting comprehensive study and examination. With respect to this fact that the customer is the basis and focus of banking system, customer-oriented perspective is considered as the most beneficial and appropriate strategy for banks (Antreas et al., 2001). The employee's behavior and their attitudes influence customer's perceptions of offered services, customer's satisfaction, their behavioral intentions, and their loyalty. Therefore, recognizing levels of needs and wants and effective components of organizational citizenship behavior on customer's satisfaction is necessary to develop of banking industry. Also, examining results of evaluations and satisfaction levels of offered services and also their employee's behavior is critical step in this process. Hence, the main purpose of this study was recognizing and examining the relationship of organizational citizenship behavior on customer's satisfaction in city of Kerman through PAC model.

\section{Review Research backgrounds}

Customer satisfaction is the sense or attitude of customer about products and services after its consumption (Ahmad and Kamal, 2002). This acts as the relationship between different stages of consumer's buying behavior. Many people intend to the things that can't seize them and then choose and satisfy their needs and wants in the areas that there are less tendency to them. Therefore the concept of satisfaction refers to comprehensive dimensions of intentions and utilities in terms of satisfying basic or excellence needs that the customer achieves because of different characteristics of products and also is the source of profitability for organization and main reason of its survival(Paulin et al., 2006).In the nowadays competitive world, only those which companies will be successful that are able to satisfy their customer's needs and also maintain and increase it. Therefore, the proactive and excellence organizations effort to ensure certainty about their customer's satisfaction (Leon, 1996). Many studies and researches are conducted in terms of examination and evaluation of customer satisfaction that some of them are cited at the following section.

Zarrabi (2004) examined satisfaction of customers and also utilized Pearson correlation coefficient and Freedman analysis to this. His results indicated that there is significant and positive relationship between quality of services and customer satisfaction and also there are significant relationships among components of services quality. Divandari (2009) examined 
and evaluated satisfaction of customers in banking industries through designing a model and applying it. Hashemzadeh (2009) examined the effective factors on customer's satisfaction in banking industry. The results of his study indicated that the service quality influences customer's satisfaction (0.44) and then are customer's educational levels, customer's attitude toward employees $(0.33)$, their evaluation from banking procedures and policies $(\mathrm{R}=0.28)$, and customer basis (0.07) explain customer's satisfaction. In another study, the paths and factors that lead to offering satisfying services to customers have been examined and tested. The results of this study indicated some factors leads to customer's satisfaction from offered services. These factors include customer's previous experiences, overall justice in the bank, feedback from customer, perceived organizational supportiveness, similarity between employees and customers, and customer's interest to employees (Ahmadi and Puorashraf,2005).

\section{Organizational citizenship behavior}

Organizational citizenship behavior refers to set of employee's organizational roles-related behaviors that are beyond their functional expectations. Though the formal system of organizational awarding doesn't identify these behaviors, but is necessary to organizational performance (Kwantes, 2003; Moorman et al., 1995). The examination of research backgrounds indicated that there is no study in terms of dual organizational citizenship behavior and customer's satisfaction in Iran and this study is necessary in these terms.

\section{Hypotheses}

In this study, the relationships among components of organizational citizenship behavior and customer's satisfaction at Kerman Saderat bank have been examined. Therefore, the hypotheses of this study formulated as follows section:

H1: employee's social interactions with customer influence their satisfaction.

H2: employee's good personal features with customer influence their satisfaction.

H3: employee's social interactions explained by employee's answers include employee's encounter, attention to customer, method of speaking with customer, employee's responsibility, directing customers by employees, attention to customer's work, bank's relationships with its customers, dean trustworthiness, clarity and perceptibility of employee's responding.

H4: employee's good personality traits explained by their apparent symmetry, reliability, crusty, employee's relationships with customers. Levels of employee's interest to their job, include general and professional abilities of employees, and respect to customers.

\section{Research purposes}

The main purposes of this study are to:

1: identifying and examining measures of customer's satisfaction in terms of organizational citizenship behavior at Kerman Saderat bank.

2: determining the effect of employee's social relationships, as the first dimension of organizational behavior, on customer's satisfaction. 
3: determining the effect of employee's personal features, as the second dimension of organizational behavior, on customer's satisfaction.

\section{Research methodology}

\subsection{Statistical population and data collecting method}

In order to collect data for the present study, the questionnaire method has been utilized. This questionnaire consists of three sections that two of them are questions about employee's social interactions and employee's personal features, and the third section is about customer's satisfaction. With respect to the purpose of this study, dependent variable is levels of customer satisfaction in Kerman Saderat bank and independent variables are employee's social interactions with their customers and their personal features. The questionnaire was based on its framework (SERVPERF). To measure reliability of questionnaire, Cronbach's Alpha coefficient was used and calculated at 0.89 . Then in order to measuring validity of this questionnaire, it was distributed among some of professors and professionals at this field and then their suggestions and corrections were applied and the final version of questionnaire was designed. In order to analyzing data and concluding results, SPSS has been used. To collect data, 200 questioners were distributed among bank's customers through random sampling method. In order to determining the effective dimensions of organizational citizenship behavior on customer's satisfaction, principal factor analysis was used. This method has been used for converting primary variables to new combined and independent variables (with zero correlation coefficient for each dimension). The new formed dimensions are combinative from the primary variables (Liu et al, 2003). In these two methods rather than using primary variables directly, first they converted to new dimensions and then these dimensions have been utilize rather than the primary dimensions. In this study because of all of variables have been utilized to formulate new dimensions, information of the primary dimensions achieved through rare efforts and this don't leads to data missing (Johnson and Wichern, 1982).

\section{Results}

7.1. The results of correlation coefficient between customer's satisfaction and dimensions of organizational citizenship behavior

Results of analyzing demographic variables such as age, educational levels, gender, and occupation of customers indicated that most of respondents were male and were in 20-40 years old and also were employed or self-employed. Table 1 show that the correlation of customer's satisfaction indicated through employee's social relationships with their customers and employee's personality traits. There is significant correlation between employee's social relationships and customer's satisfaction $(\mathrm{R}=0.738)$, employee's personality traits and customer's satisfaction $(R=0.736)$. These values indicated that these two variables have relationship with customer's satisfaction. These values are significant at $\mathrm{p}<0.01$ and then two hypotheses accepted. The conceptual framework of this study indicated at the fig 1 .

\section{Conclusion}

In this article with respect to the importance of evaluating customer's satisfaction in banking 
industry, first some of customer satisfaction concepts described and then organizational citizenship behavior offered. Then the model of evaluating customer satisfaction with organizational citizenship behavior designed through factor analysis. The main purpose of this study was to examining the relationship between customer's satisfactions and components of organizational citizenship behavior at Kerman Saderat bank. In order to collecting data, two questionnaires, including organizational citizenship behavior and customer satisfaction was used. Pearson correlation coefficient and factor analysis were used to analyze data and conclude results. The results of this study indicated that six primary variables could explain $87 \%$ of variation of all data in terms of social relationships and the main components of this include attention to customer, speaking with customers, and direction by customers, attention to customer's affairs by employees, bosses' responsibility, and clarity of answers. The responsibility of bosses was the most important factor among the main factors in terms of employee's social relationships and also the attention to customer's work by employees had the less importance. Also, the results of employee's personality traits indicated that the five primary factors could explain $92 \%$ of customer satisfaction and the main factors in terms of this include apparent symmetry, reliability, ability to communicate, the general and professional ability. The reliability was the main factor and the ability to communicating was the less effect on customer satisfaction. Finally, it should be remembered that results of such studies could leads to recognizing effective behaviors on customer's satisfaction. Also, the positive effects of such studies can leads to examining reasons of unrecognized behaviors that are the main factor of increasing effectiveness with more recognition and appropriate insight. Therefore, it should attended that there some studies in terms of creating, encouraging, improving, and reinforcing such behaviors, regardless of different studies that conducted in terms of different dimensions of organizational citizenship behavior and its importance in organizational citizenship.

\section{References}

Ahmadi, P., Porashraf, Y., (2007), the path of Customer's Satisfaction in Commercial banks, Journal of Human Sciences, 11(3), pp 29-58.

Ahmad, J. and Kamal, N. (2002).Customer satisfaction and retailbanking: an assessment of some of the key antecedents of customersatisfaction in retail banking. International Journal of Bank Marketing, 20: 146-160.

Antreas, A., Spiros, G. and Valssis, S. (2001). Behavioral responses to customer satisfaction: an empirical study.European Journal of Marketing, 35: 687-707.

Divandari, A., Delkhah, G., (2005), Developing and Designing a Model for Evaluation of Customer's Satisfaction and Evaluating Customer's Satisfaction based on it, Journal of Commercial studies, Vol. 37, pp. 185-223.

Hafezi, S., Naghibi, H., Naderi, A., Najafimehri, S., and Mahmodi, H., (2008), the examination of Relationship between Individual Skills with Organizational Behavior of Time management among Educational managers, Kournal of Behabioral sciences, 2(2), 183-192.

Hashemzadeh, D., (2009), the Examination of Influencing Factors on Customer's Satisfaction, Journal of Business management, 1(2), pp 63-82. 


\section{Macrothink}

Journal of Public Administration and Governance ISSN 2161-7104 2012, Vol. 2, No. 2

Hoseyni, Q., Bejani, H., Malekinia, A., (2010), the Influencing Factors, Dimensions, and Outcomes of Organizational Citizenship Behavior, monthly of Police development, 7(13).

Johnson, R. A. and Wichern, D. W. (1982). Applied multivariate statistical analysis. Prentice-Hall Inc., Englewood Cliffs, SA, 590 pp.

Kwantes, C.T. (2003).Organizational citizenship and withdrawal behaviors in USAand India. International Journal of Cross Cultural Management, 3 (1), p. 5.

Leon, W. (1996). Learning Organization: From Idea to Action. HumanResource Management, December, Vol.6.

Liu, C. W., Lin, K. H. and Kuo, Y. M. (2003). Application of factor analysis in the assessment of groundwater quality in a blackfoot disease area in Taiwan. The Science of the Total Environment, 313: 77- 89.

Moorman, R.H. and Blakely, G.L. (1995).Individualism-Collectivism as anindividual difference predictor of organizational citizenship behavior.Journal of Organizational Behavior, $16: 127-142$.

Paulin, M., Ferguson, R.J. and Bergeron, J. (2006). Service climate and organizational commitment: The importance of customer linkages. Journal of Business Research, 59: 906-915.

Zarabi, S., (2004), Examining and Evaluating Services in Saderat Bank and its Relationship with Customer's Satisfaction, MA Thesis, Faculty of management and accounting, ShahidBeheshti University.

Table 1: the results of correlation coefficient between customer's satisfaction and dimensions of organizational citizenship behavior

\begin{tabular}{|l|l|l|l|}
\hline Dimensions & $\begin{array}{l}\text { Employee's social } \\
\text { relationships with } \\
\text { customers }\end{array}$ & $\begin{array}{l}\text { Employee's personality } \\
\text { traits }\end{array}$ & $\begin{array}{l}\text { Customer's } \\
\text { satisfaction }\end{array}$ \\
\hline $\begin{array}{l}\text { Employee's social } \\
\text { relationships with } \\
\text { customers }\end{array}$ & 1 & 0.836 & 0.738 \\
\hline $\begin{array}{l}\text { Employee's personality } \\
\text { traits }\end{array}$ & 0.836 & 1 & 0.736 \\
\hline Customer's satisfaction & 0.738 & 0.736 & 1 \\
\hline
\end{tabular}




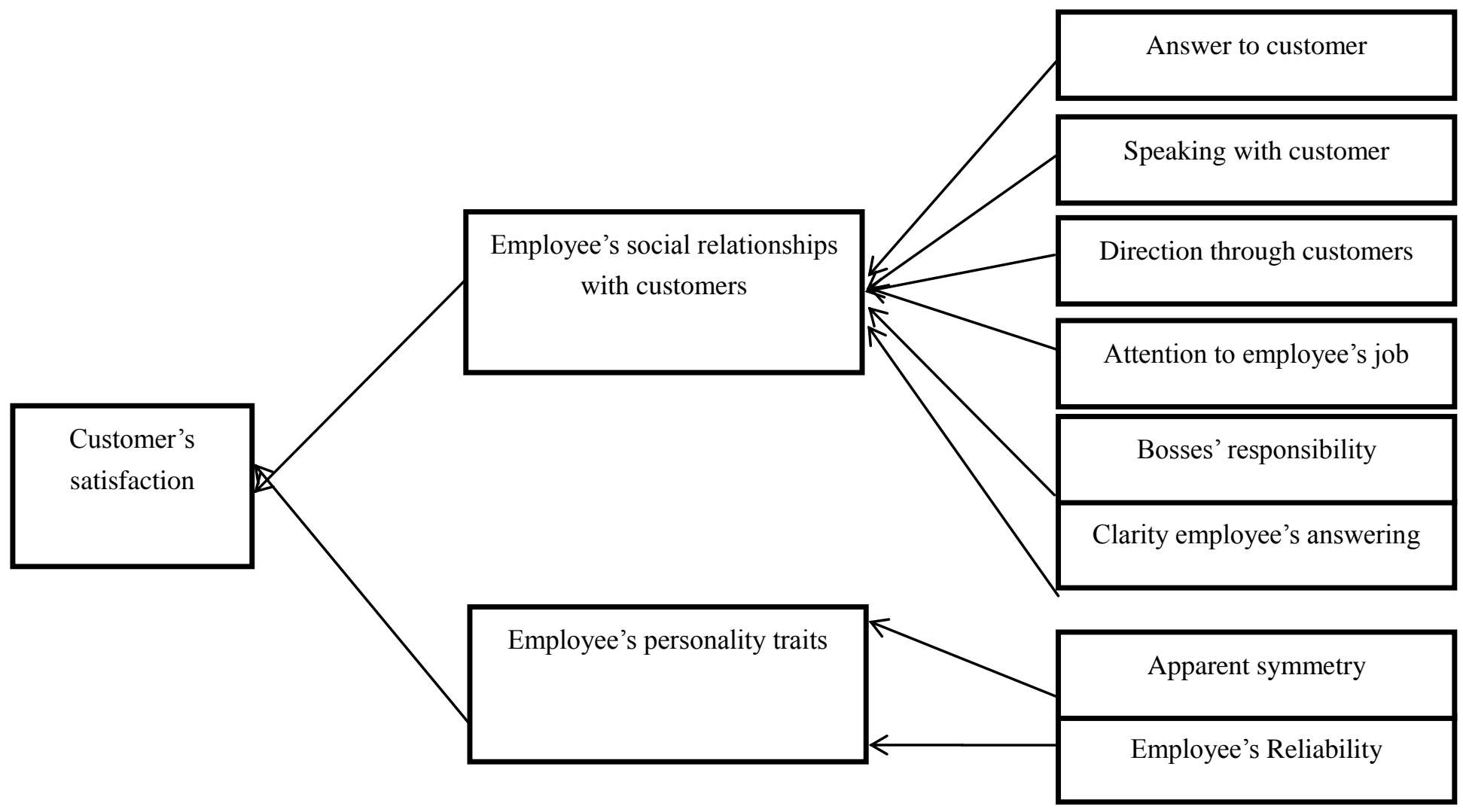

Fig 1: the conceptual framework of effective dimensions of organizational citizenship behavior on customer's satisfaction and its results 